\title{
GLP-1, SGLT-2, new devices for interventional cardiologists
}

In this issue, we are pleased to have an excellent review about an up-to-date review by Kilıçkap et al. from Turkey of cardiovascular (CV) outcome trials of GLP-1 receptor agonists and SGLT-2 inhibitors interpreting study characteristics and results of these studies. This review will shed light on diabetes mellitus, CV disease (CVD), and new antidiabetic drugs.

Liang et al. from China aimed to evaluate the efficacy and safety of edoxaban versus warfarin in the prevention of clinical events in patients with atrial fibrillation (AF) through a meta-analysis of randomized controlled trials. The results will contribute to the literature.

Myocardial injury after noncardiac surgery is important. Keskinler et al. from Turkey studied to assess the risk of perioperative myocardial infarction among patients with a moderate- or high-risk Framingham score and what could be done for it.

Percutaneous pulmonary valve implantation (PPVI) into right ventricle-to-pulmonary artery conduits is being increasingly performed, but there are few options for patients with a dilated native right ventricular outflow tract (RVOT). Güzeltaş et al. from Turkey give their results on the Edwards SAPIEN XT and S3 valves as an alternative for PPVI in patients with dilated native RVOT.

Hammami et al. from United Arab Emirates evaluated the incidence, prognostic significance, and survival outcomes of primary cardiac sarcoma as an updated population-based retrospective study.

Sinha et al. from India designed a study to evaluate the safety and effectiveness of an ultra-long $(\geq 40 \mathrm{~mm})$ and ultra-thin (60 $\mu \mathrm{m}$ ) biodegradable polymer-coated sirolimus-eluting stent, Supralimus Grace with a unique Long Dual Z link design (Sahajanand Medical Technologies Pvt. Ltd., Surat, India), in real-world patients with long coronary lesions. I hope the results will be useful for interventional cardiologists.

Mahdavi-Roshan et al. from Iran conducted a study to assess the prevalence of central and general obesity and to compare nine anthropometric indices as predictors of CVD risk factors in Iranian adults. The results of this study will add new data to the international database.

'Genetic variants associated with atrial fibrillation and long term recurrence after catheter ablation for atrial fibrillation in Turkish patients' is a very complex study done by Ulus et al. from Turkey. The authors claim that their findings suggest that genetic factors may play an important role in the pathogenesis of $\mathrm{AF}$.

This issue also includes many interesting case reports and e-page originals.

I hope this issue will be of interest to our readers.

Prof. Dr. Cetin Erol

Editor-in-Chief

Ankara-Turkey

Address for Correspondence: Prof. Dr. Çetin Erol, Ankara Üniversitesi Tıp Fakültesi, İbn-i Sina Hastanesi, Kardiyoloji Anabilim Dalı, Ankara, Türkiye

Phone: +90 3123103333 /27 79 E-mail: ctnerol@yahoo.com

(C) Copyright 2021 by Turkish Society of Cardiology - Available online at www.anatoljcardiol.com

DOI:10.5152/AnatolJCardiol.2021.2 